\title{
Genetic variability analysis for various yield attributing traits in rice genotypes
}

\author{
M. M. Rashid, M. Nuruzzaman, L. Hassan* and S. N. Begum ${ }^{1}$ \\ Department of Genetics and Plant Breeding, Bangladesh Agricultural University (BAU), Mymensingh-2202 and ${ }^{1}$ Plant \\ Breeding Division, Bangladesh Institute of Nuclear Agriculture (BINA), Mymensingh-2202, Bangladesh \\ *E-mail: lutfulhassan@yahoo.co.uk
}

\begin{abstract}
An experiment was conducted using a randomized complete block design to estimate genetic variability of ten rice genotypes. Analysis of variance for yield and yield contributing traits showed significant $(p<0.01)$ variation among the genotypes. Results of genetic analyses showed a higher phenotypic coefficient of variation compared to their corresponding genotypic coefficient of variation for all the traits measured, which indicates that the traits were influenced by environment. The magnitude of difference between phenotypic coefficient of variance (PCV) and genotypic coefficient of variance (GCV) was less for the traits indicating little influence of environment. The higher estimates of PCV and GCV were observed for number of filled grains panicle ${ }^{-1}(27.53 ; 26.84)$, number of unfilled grains panicle ${ }^{-1}(26.76 ; 25.28)$ and plant height $(23.14 ; 23.00)$ indicates possibility of genetic improvement through direct selection for these traits, while days to $50 \%$ flowering, days to maturity, panicle length, number of effective tillers plant ${ }^{-1}$, fertility (\%), 1000 Seed weight and yield panicle ${ }^{-1}$ showed low PCV and GCV values indicating the need for creation of variability by hybridization or mutation followed by selection. High heritability values (>60\%) along with high genetic advance and genetic advance as percentage of mean were found for all the traits indicating prevalence of additive gene action, which provides good scope for further improvement by selection.
\end{abstract}

Keywords: Genetic variability, Heritability, Genetic advance, Rice genotypes

\section{Introduction}

Rice (Oryza sativa L.) is one of the most important food crops in the world. It is a staple food crop for more than half of the world's human population.Bangladesh stands fourth with 52.2 million tons as China occupies the first place with 206.5 million tons in the world's production table of 479.3 million tons (FAOSTAT, 2014).Yield and yield contributing parameters are the most widely targeted traits for rice improvement programmes worldwide. The improvement of a crop is largely dependent on the nature and magnitude of available genetic variability, heritability and the transfer of desired characters into new varieties. The success of breeding programmes can be enhanced when variability within the existing germplasm is high, which allows the plant breeder to more rapidly produce new varieties or improve existing ones (Meena and Bahadur, 2013, 2014; Ranganatha et al., 2013; Yared and Misteru 2016). Hence, knowledge of key genetic parameters is crucial for any crop improvement program, providing precise information for selection. Genetic parameters like the genotypic coefficient of variation (GCV), phenotypic coefficient of variation (PCV), heritability and genetic advance (GA) are useful biometric tools for measuring genetic variability (Aditya et al., 2011). Hence, characterising the genetic background of rice and determining breeding values should be done before carrying out any improvement programme (Agong et al., 2001). Yield is a complex polygenic character, resulting from multiple interactions between many yield contributing traits.

Considering the above facts, the present research study was undertaken to estimate genetic variability, heritability and genetic advances among yield and yield contributing traits for rice genotypes. This investigation provides information that could lead to the development of desirable rice genotypes for salt tolerant in future breeding programmes. 


\section{Materials and Methods}

The present experiment was carried out in the Net House of the Plant Breeding Division at Bangladesh Institute of Nuclear Agriculture (BINA), Mymensingh during the period from June to December 2015. Ten rice genotypes including seven landraces and three released varieties viz., Hogla, Dakh Shail, Kute Patnai, Ghunshi, Mondeshor, Tal Mugur, Nona Bokhra, Binadhan-8, Binadhan-10 and BRRI dhan47 were used as plant material. The experiment was carried out in a Randomized Complete Block Design with five replications. Management practices such as irrigation and fertilization were performed by following the standard procedures (IRRI 2002). Other intercultural operations were done whenever necessary.

Morphological data were collected at appropriate growth stage of rice plant following the standard evaluation system indicated by IRRI (IRRI 2002). The characters that were evaluated included days to $50 \%$ flowering, days to maturity, plant height $(\mathrm{cm})$, panicle length $(\mathrm{cm})$, number of effective tillers plant $^{-1}$, number of filled grains panicle ${ }^{-1}$, number of unfilled grains panicle ${ }^{-1}$, fertility (\%), 1000 Seed weight (g) and yield panicle ${ }^{-1}(\mathrm{~g})$.

The recorded data for different parameters were assembled and organized properly for statistical analysis using MSTAT-C. Genotypic and phenotypic variances were estimated according to the formula given by (Johnson et al., 1955). Heritability was estimated according to the formula suggested by (Johnson et al., 1955 and Hanson 1961). Genotypic and phenotypic coefficient of variance was estimated according to (Burton, 1952 and Singh et al., 1997). Estimation of GA was done following formula given by (Johnson et al., 1955 and Allard, 1975) and GA\% was calculated by the formula suggested by (Comstock et al., 1952).

\section{Results and Discussion}

\section{Analysis of variance}

The analysis of variance showed (Table 1) that the difference among genotypes for all the traits under study were highly significant for genotypes, treatment and genotypes-treatment interaction. This indicated that the genotypes were possessing inherent genetic variances among themselves with respect to the characters studied. Similar results were reported by (Bekele et al., 2013).

Table 1. Analysis of variance for different morphological plant characters of ten rice genotypes

\begin{tabular}{|c|c|c|c|c|c|c|c|c|c|c|c|}
\hline Characters & $\mathrm{df}$ & $\begin{array}{c}\text { Days to } \\
50 \% \\
\text { flowering }\end{array}$ & $\begin{array}{l}\text { Days to } \\
\text { maturity }\end{array}$ & $\begin{array}{l}\text { Plant } \\
\text { height } \\
(\mathrm{cm})\end{array}$ & $\begin{array}{l}\text { Panicle } \\
\text { length } \\
\text { (cm) }\end{array}$ & $\begin{array}{c}\text { No of } \\
\text { effective } \\
\text { tillers plant-1 }\end{array}$ & $\begin{array}{c}\text { No of filled } \\
\text { grains } \\
\text { panicle-1 }\end{array}$ & $\begin{array}{c}\text { No of unfilled } \\
\text { grains } \\
\text { panicle-1 }\end{array}$ & $\begin{array}{c}\text { Fertility } \\
(\%)\end{array}$ & $\begin{array}{c}1000 \text { seed } \\
\text { weight } \\
\text { (g) }\end{array}$ & $\begin{array}{c}\text { Yield } \\
\text { panicle }^{-1} \\
\text { (g) }\end{array}$ \\
\hline Replication & 4 & 28.93 & 15.72 & 60.18 & 0.27 & 0.338 & 26.60 & 2.134 & 18.28 & 4.07 & 0.032 \\
\hline Genotypes (A) & 9 & $2070.09 * *$ & $2896.07^{* *}$ & 15050.54 ** & $96.72^{\star *}$ & $7.789^{\star *}$ & $11531.17^{\star *}$ & $1261.581^{\star *}$ & $1435.60^{\star \star}$ & $251.71^{\star *}$ & $3.334^{* *}$ \\
\hline Treatment (B) & 3 & $105.17^{\star *}$ & $734.05^{\star *}$ & $3139.77^{* *}$ & $250.04^{\star \star}$ & $90.413^{* *}$ & $30740.87^{\star *}$ & $7858.686^{\star *}$ & $14941.98 * *$ & $725.27^{\text {** }}$ & $42.503^{\star \star}$ \\
\hline$A \times B$ & 27 & $28.27^{*}$ & $53.58 * *$ & $220.75^{\star \star}$ & $85.23^{* *}$ & $2.202^{\star \star}$ & $703.28^{* *}$ & $599.999 * *$ & $750.24^{\star *}$ & $84.79 * *$ & $0.706^{* *}$ \\
\hline Error & 156 & 16.55 & 23.07 & 25.97 & 2.28 & 0.435 & 11.28 & 0.924 & 5.26 & 5.59 & 0.015 \\
\hline
\end{tabular}

** Indicates significant at 0.01 probability level and * indicates significant at 0.05 probability level

\section{Estimate of genetic parameters}

Estimates of phenotypic $\left(\delta^{2} p\right)$ and genotypic variances $\left(\delta^{2} g\right)$, phenotypic coefficient (PCV) and genotypic coefficient of variance (GCV), heritability (\%), genetic advance (GA) and genetic advance as percent of mean (GA\%) are shown in Table 2. High phenotypic and genotypic variances were recorded with plant height 750.58 and 741.49 , respectively. High phenotypic and genotypic variances were equally observed for number of filled grains panicle ${ }^{-1}$ (569.64 and 541.39), days to maturity (144.50 and 142.12) and days to $50 \%$ flowering (103.39 and 102.09), respectively. The low values of phenotypic and genotypic variances were observed with the characters yield panicle ${ }^{-1}(0.16$ and 0.13$)$, number of effective tillers plant $^{-1}(0.372$ and 0.279$)$ and panicle length (0.620 and 0.575$)$, respectively. In general, the phenotypic variances were higher than genotypic variances for all the characters. 
Table 2. Phenotypic $\left(\delta^{2} p\right)$ and genotypic variance $\left(\delta^{2} g\right)$, phenotypic coefficient (PCV) and genotypic coefficient of variance (GCV), heritability (\%), genetic advance (GA) and genetic advance as percent of mean (GAM) for all the traits

\begin{tabular}{lccccccc}
\hline \multicolumn{1}{c}{ Characters } & $\begin{array}{c}\text { Phenotypic } \\
\text { variance }\left(\delta^{2} \mathrm{p}\right)\end{array}$ & $\begin{array}{c}\text { Genotypic } \\
\text { variance }\left(\delta^{2} \mathrm{~g}\right)\end{array}$ & $\begin{array}{c}\text { PCV } \\
(\%)\end{array}$ & $\begin{array}{c}\text { GCV } \\
(\%)\end{array}$ & $\begin{array}{c}\text { Heritability } \\
(\%)\end{array}$ & GA & GAM \\
\hline Days to 50\% flowering & 103.39 & 102.09 & 9.63 & 9.57 & 98.75 & 20.68 & 19.59 \\
Days to maturity & 144.50 & 142.12 & 8.74 & 8.67 & 98.36 & 24.36 & 17.71 \\
Plant height $(\mathrm{cm})$ & 750.58 & 741.49 & 23.14 & 23.00 & 98.79 & 55.75 & 47.09 \\
Panicle length (cm) & 0.620 & 0.575 & 3.44 & 3.32 & 92.73 & 1.50 & 6.58 \\
No of effective tillers plant $^{-1}$ & 0.372 & 0.279 & 11.73 & 10.16 & 75.14 & 0.94 & 18.15 \\
No of filled grains panicle $^{-1}$ & 569.64 & 541.39 & 27.53 & 26.84 & 95.04 & 46.73 & 53.90 \\
No of unfilled grains $_{\text {panicle }}^{-1}$ & 37.08 & 33.08 & 26.76 & 25.28 & 89.21 & 11.19 & 49.18 \\
Fertility (\%) $_{1000 \text { Seed weight (g) }}$ & 36.33 & 34.27 & 7.93 & 7.70 & 94.32 & 11.71 & 15.41 \\
Yield panicle $^{-1}(\mathrm{~g})$ & 9.79 & 8.35 & 14.77 & 13.64 & 85.25 & 5.49 & 25.94 \\
& 0.16 & 0.13 & 20.44 & 18.54 & 82.23 & 0.68 & 34.63 \\
\hline
\end{tabular}

The phenotypic coefficients of variance (PCV) were ranged from $3.44 \%$ for panicle length to $27.53 \%$ for number of filled grains panicle ${ }^{-1}$, whereas genotypic coefficients of variance (GCV) were ranged from $3.32 \%$ for panicle length to $26.84 \%$ for number of filled grains panicle ${ }^{-1}$.According to Siva Subramanian and Menon (1973) PCV and GCV values more than $20 \%$ are regarded as high, whereas values less than $10 \%$ are considered to be low and values between 10 and $20 \%$ to be moderate. Based on this delineation, PCV and GCV values were high for plant height, number of filled grains panicle ${ }^{-1}$ and number of unfilled grains panicle ${ }^{-1}$; low for days to $50 \%$ flowering, days to maturity, panicle length and fertility percent; medium for number of effective tillers plant ${ }^{-1}$ and 1000 seed weight. The yield panicle ${ }^{-1}$ was recorded with high PCV and moderate GCV.

The current study suggests that phenotypic variance $\left(\delta^{2} p\right)$ and phenotypic coefficient variance (PCV) were higher than theirs corresponding genotypic variance $\left(\delta^{2} g\right)$ and genotypic coefficient of variance (GCV) respectively for all the characters studies, indicating that the expression of these characters was influenced by environment. Similar results were reported by (Dutta et al., 2013; Singh et al., 2014; Tuhina-Khatun et al., 2015) in rice. The trait like yield panicle ${ }^{-1}$ which show higher difference between PCV and GCV indicated that environmental effect on the expression of those traits is higher.

Heritability analysis estimates the relative contributions of differences in genetic and non-genetic factors to the total phenotypic variance in a population. It is an important concept in quantitative genetics, particularly in selective breeding. The heritability estimation varied form $75.14 \%$ to $98.79 \%$, respectively for number of effective tillers plant ${ }^{-1}$ and plant height. All the characters studies had high heritability $(>60 \%)$. This result indicates that these characters could be easily improved by selection. The most important function of the heritability in the genetic study of quantitative characters is its predictive role to indicate the reliability of the phenotypic value as a guide to breeding value (Falconer and Mackay 1996 and Al-Tabbal et al., 2012). High heritability estimates for those traits indicated a high response to selection in these traits. Similar results were also reported by (Al-Tabbal et al., 2012; Dutta et al., 2013; Raffi et al., 2014), which support the present findings.

Genetic advance (GA) under selection refers to the improvement of characters in genotypic value for the new population compared with the base population under one cycle of selection at a given selection intensity (Wolie et al., 2013). The high value of GA was recorded with plant height (55.75) and the low (0.68) with yield panicle ${ }^{-1}$. Estimates of GA for yield panicle ${ }^{-1}$ was $(0.68 \mathrm{~g})$ indicating that whenever we select the best, $1 \%$ high yielding genotypes as parents, average grains yield panicle ${ }^{-1}$ of progenies could be improved by $0.68 \mathrm{~g}$ panicle ${ }^{-1}$. Genetic advance as percent mean expected (GAM) had a general range between $6.58 \%$ for panicle length and $53.90 \%$ for number of filled grains panicle ${ }^{-1}$.Among the characters high values of GAM $(>20 \%)$ were recorded for plant height, number of filled grains panicle ${ }^{-1}$, number of unfilled grains panicle ${ }^{-1}, 1000$ seed weight and yield panicle ${ }^{-1}$. It was moderate (10 to $\left.20 \%\right)$ for days to $50 \%$ flowering, days to maturity and fertility percent; low $(<10 \%)$ for only panicle length. 
Heritability and the genetic advance are also important selection parameters. It is more useful as a selection tool when considered jointly with heritability. The estimates of genetic advance can help to understand the type of gene action of various polygenic characters. (Johnson et al., 1955) suggested that high heritability estimates along with the high genetic advance is more helpful in predicting gain under selection than heritability estimates alone. Thus, the heritability estimates will be reliable if accompanied by high genetic advance. (Patel et al., 2012) also observed highest heritability for days to 50\%flowering, plant height, total tillers, panicle length, number of filled grain panicle ${ }^{-1}$, number of unfilled grain panicle ${ }^{-1}$ and grains yield $\mathrm{m}^{-2}$.

The present study revealed high heritability accompanied with high genetic advance as percent of the mean for plant height, number of filled grains panicle ${ }^{-1}$, number of unfilled grains panicle ${ }^{-1}, 1000$ seed weight and yield panicle ${ }^{-1}$; high heritability and moderate genetic advance as percent of the mean for days to $50 \%$ flowering, days to maturity and fertility percent; These results could be explained by additive gene action and their selection may be done in early generations. Similar findings have been reported by (Wolie et al., 2013 and Ogunbayo et al., 2014) on rice and (Reza et al., 2015) on wheat. Panicle length, days to $50 \%$ flowering, days to maturity and fertility percent had low to moderate genetic advance as percent of the mean indicates non-additive gene effects; suggesting that these characters could be improved by developing varieties through recurrent selection method (Ogunbayo et al., 2014).

The results of the present study on variability, heritability and genetic advance indicated scope for improvement of rice grain yield through selection, using parameters like the genetic coefficient of variation, heritability and GA and are of great importance when developing an efficient breeding program for rice, because when there is sufficient genetic variation, breeders can exploit additive gene effects, transgressive segregation, and heterosis to improve yield.

\section{Acknowledgements}

The authors are thankful to the Plant Breeding Division, Bangladesh Institute of Nuclear Agriculture (BINA), Mymensingh. Financial support from Ministry of Science and Technology, Bangladesh is also acknowledged.

\section{References}

Agong, S.G., Schittenhelm, S. and Fried, W. 2001. Genotypic variation of Kenyan tomato (Lycopersicon esculentum Mill.) germplasm. Journal of Food Technology in Africa. 6(1): 13-17.

Al-Tabbal, J.A. and Al-Fraihat, A.H. 2012. Genetic variation, heritability, phenotypic and genotypic correlation studies for yield and yield components in promising barley genotypes. J. Agric. Sci. 4:3.

Allard, R.W. 1975. Principles of plant breeding, John Wiley and Sons Incorporation, New York.

Bekele, B.D., Naveen, G.K., Rakhi, S. and Shashidhar, H.E. 2013. Genetic evaluation of recombinant inbred lines of rice (Oryzasativa L.) for grain zinc concentrations, yield related traits and identification of associated SSR markers. Pakistan Journal of Biological Sciences 16(23): 1714-1721.

Burton, G.W. 1952. Quantitative inheritance in grasses, Proc. $6^{\text {th }}$ International Grassland Cong., 1: 277-283.

Comstock, R., Robinson, H. and Gowen, J. 1952. Estimation of average dominance of genes, Heterosis, 494-516.

Dutta, P., Dutta, P.N. and Borua, P.K. 2013. Morphological Traits as Selection Indices in Rice: A Statistical View. Univ. J. Agric. Res. 1(3):85-96.

Falconer, D.S, and Mackay, T.F.C. 1996. Introduction to quantitative genetics. 4th Edn., Benjamin Cummings, England, ISBN10:0582243025.

FAOSTAT. 2014. Statistical data base. Food and Agriculture Organizations of the United Nations. Rome, Italia.

Hanson, W.D. 1961. Heritability, statistical genetics and plant breeding, National Academy of Science, National Research Council, Washington pp.125-140.

IRRI. 2002. Standard evaluation system for rice. International Rice Research Institute, Manila.

Johnson, H.W., Robinson, H.F. and Comstock, R.E. 1955. Estimation of genetic and environmental variability in soybeans. Agron. J. 47:314-318.

Meena, O.P. and Bahadur. V. 2013. Assessment of breeding potential of tomato (Lycopersicon esculentum Mill.) germplasm using $D^{2}$ analysis. The Bioscan 8: 1145-1148. 
Rashid et al.

Meena, O.P. and Bahadur. V. 2014. Assessment of genetic variability, heritability and genetic advance among tomato (Solanumlycopersicum L.) germplasm. Agricultural Science Digest 27: 185-192.

Ogunbayo, S.A., Sié, M., Ojo, D.K, Sanni, K.A., Akinwale, M.G., Toulou, B., Shittu, A., Idehen, E.O., Popoola, A.R., Daniel, I.O. and Gregoria, G.B. 2014. Genetic variation and heritability of yield and related traits in promising rice genotypes (Oryza sativa L.). J. Plant Breed. Crop Sci. 6(11): 153-159.

Patel, A., Chaudhari, P.R. and Verulkar, S.B. 2012. Analysis of genetic variability, heritability and genetic advance for yield and yield components in rice (Oryza sativa L.) under different water regimes. Plant Archives. 12(1) 425-435.

Raffi, M.Y., Zakiah, M.Z., Asfaliza, R., Iffah. H.M.D., Latif, M.A. and Malek. M.A. 2014. Grain quality performance and heritability estimation in selected rice genotypes. Sains Malaysiana 43(1): 1-7.

Ranganatha, H.M., Patil, S.S., Manjula, S.M. and Arvindkumar, B.N. 2013. Genetic variability studies in segregating generation of upland cotton (Gossypium hirsutum L.), Molecular Plant Breeding 4: 84-88.

Reza, M. and Pour, F. 2015. Investigation of genetic variation for agronomic traits among the recombinant inbred lines of wheat from the norstar $\times$ zagross cross under water stress condition. Intl. J. Biol. Biomol. Agric. Food Biotechnol. Eng. 9: 9.

Singh, A., Singh, A.K., Singh, V., Singh, N., Singh, V.N., Shamin, M., Vikram, P. and Singh, S. 2014. Genetic variability among traits associated with grain yield of rice (Oryza sativa L.) exposed to drought at flowering stage. Afr. J. Res 9 (16): 1252.

Singh, D.N., Sahu, A. and Parida, A.K. 1997. Genetic variability and correlation studies in tomato (Lycopersicon esculentum Mill.), Journal of Environment and Ecology 15: 135-141.

Sivasubramanian, S. and Menon, M. 1973. Heterosis and inbreeding depression in rice. Madras Agric. J 60:1139.

Tuhina-Khatun, M., Hanafi, M.M., Yusop, M.R., Wong, M.Y., Salleh, F.M. and Ferdous, J. 2015. Genetic variation, heritability, and diversity analysis of upland rice (Oryza sativa L.) genotypes based on quantitative traits. BioMed. Res. Intr. ID 290861.

Wolie, A., Dessalegn, T. and Belete, K. 2013. Heritability, variance components and genetic advance of some yield and yield related traits in Ethiopian collections of finger millet (Eleusine coracana (L.) Gaertn.) genotypes. Afr. J. Biotechnol 12(36): 55295534.

Yared, S. and Misteru, T. 2016.Variability, heritability and genetic advance analysis for some morphological characters in oilseed brassica breeding lines. Molecular Plant Breeding 7(20): 1-8. 